\title{
The Impact of Job Demands and Job Resources on Work Family Con- flict: Mediating effect of Emotional Exhaustion and Moderating effect of Job Demands and Job Resources A Conceptual Framework for Research
}

\author{
S.M.D. Yasodara Jayarathna \\ Department of Human Resource Management \\ Faculty of Commerce and Management Studies \\ University of Kelaniya \\ dinethiyasodara@kln.ac.lk
}

\begin{abstract}
Busy schedules in this contemporary world widen the boundaries between family life and work life, which created Work Family Conflict and has become a prevalent issue among individuals. Even though there are considerable amount of studies conducted on this area, there remain few empirical and theoretical findings on extending the Job Demands- Resource theory in to work family domain. Further, this concept paper propose the mediation effect of emotional exhaustion on the relation between job demands and job resources on work family conflict and propose the moderation effect of job demands and job resources. A conceptual model is proposed at the end of the paper that enables the future researchers to test empirically in different environments.
\end{abstract}

Keywords: Work Family Conflict, Job Demands, Job Resources, Emotional Exhaustion

Copyright: (C) 2019, S. M. D. Yasodara Jayarathna. This is an open access article distributed under the Creative Commons Attribution License, which permits unrestricted use, distribution, and reproduction in any medium, provided the original work is properly cited.

Correspondence: dinethiyasodara@kln.ac.lk

ORCID of authors: https://orcid.org/0000-0002-5964-4914

DOI: http://10.4038/kjm.v7i2.7578 


\section{Introduction}

Globalization, competition among countries, growing consumerism, continuous advancement of technology and changes in the family context are highlighted issues in this modern world that enhance the need for more money of an individual. Further, with these issues individuals are in a dilemma to allocate their time in achieving the demands and responsibilities of different roles played by them especially at work and family. Hudson Institute (1990) as cited in Liao (2011) has acknowledged that workforce in $21^{\text {st }}$ century, is different from the previous era. It conversed that both men and women struggle continuously for work and family demands with existing family responsibilities that eventually create work family conflicts. Increasing number of dual earner couples, single parents, aging parents and the societies where family work is transferred by female through entering into the labour market have created intricate interdependencies between work and family roles (Bennett, Beehr, \& Ivanitskaya, 2017; Chandra, 2012), have stimulated the researches to examine different scenarios of work family conflict (Greenhaus \& Powell 2003). With the expansion of technology with globalization, major changes have occurred in social and economic aspects and have altered the family structure and the family relationships. Hence, work and life are areas where researchers have focused more in the present turbulent context.

The normal family life individuals used to be, has changed where many individuals look for extra jobs with the purpose of enhancing economic stability (Bennett et al., 2017) and living a happy life. Further, the primary concern of an organization is efficiency and profitability (Hekman, Bigley \& Hereford 2009) where employees are compelled to work more hours than agreed. Thus, high workload and challenging family situations created work family conflict that is more predominant at work place in the present scenario, as every human being is struggling to navigate worklife balance problems. Liao (2011) has stated that countless employees are struggling because of work family conflict with these major changes in $21^{\text {st }}$ century. This appears as a cause to drain employee's energy, which has reduce time that can dedicate to family life. In doing so, high workload grow the opportunities to occur work family conflict and emotional exhaustion (Bennett et al., 2017; Tayfur \& Arslan, 2013).

Work family conflict creates strain and tension for many professionals in the current business environment (Goswami, 2014). With the advancement of information technology, overloaded information, requirement for speedy response, longer working hours, overtime and working in the weekends, have become the possible reasons to create work pressure for employees (Guest, 2002; James, 2014; Valk \& Srinivasan, 2011). Further, increasing proportion of women in the workforce and worsening the quality of families with the reduction of time to spent time with aging parents, children and spouses (James, 2014; Lee, \& Maurer, 1999) are substantial causes for growing work family conflicts in this era. These changing life patterns have created a complex scenario entail more attention for a harmonizing approach to compliment both work and life. This development has draws the attention of the academics and researchers do conduct more studies on work family conflict.

Work family conflict highlighted as a common issue among professionals. Patel (2011) found that professional who work as business travelers are experiencing work family conflict, and he stated that majority of studies on work family conflict have been conducted in the field of travel medicine. Studies on work family conflict in different industries have been 
conducted by several previous researchers; Winefield, Boyd, \& Winefield (2014 on academics, Lingard \& Francis (2005) on civil engineers and construction professionals, and Mete, Ünal, \& Bilen (2014) on accounting professionals, stressing that work family conflict is an issue that repeatedly visible among blue collar workers. Further, Liao (2011) have found that employees in Taiwan high technology industry are experiencing a high level of work family conflict. Thus, it is evident that with the changes in the social, economic and employment aspects majority of professionals are experiencing work family conflict up to a significant level.

It was apparent that job characteristics play a major role in creating work family conflict for employees. Job demands and job resources are considered as broad categories that predict work related wellbeing. Job demands are the job characteristics that potentially create stress in a situation where individuals surpass their capacity of adaptability (Hakanen, Bakker, \& Demerouti, 2005). Job resources are the psychological, physical, social or organizational aspects of a job that aid in reducing stress created by job demands and to achieve work goals eventually enhance the personal growth with learning and development (Hakanen et al., 2005). Further, it was stressed that excessive job demands produce exhaustion (Bakker \& Demerouti, 2007; Jensen, 2014) and generate work family conflict, where job resources reduce work related stress and exhaustion (Bakker \& Demerouti, 2007; Jensen, 2014) and act as a buffering factor for work family conflict.

The current study focuses on investigating the link between job demands and job resources with work family conflict. As per to the authors knowledge, there are limited studies have conducted on demonstrating the above relationship. Having identified the void of theoretical and empirical explanations up to date, the current concept paper explores the underline problem extending the job demands-resources (JD-R) theory on work family domain. Furthermore, it is expected to look whether emotional exhaustion act as a full or a partial mediator and job demands and job resources act as moderators using the explanations from the previous literature and job demands-resources theory.

\section{Literature Review}

\section{Work Family Conflict}

Work family conflict is defined as 'a form of inter-role conflict in which role pressures from the work and family domains are mutually incompatible in some respect' (Greenhaus and Beutell, 1985, p. 77). Work and family considered as the two major domains for employed adults and preferably, it is expected these domains to work successfully by being compatible with one another (Lambert, Kelley, \& Hogan, 2013). Yet, regular complications and difficulties in one domain spillover in to another and create frustrations and conflicts between these two domains. This spillover can be bidirectional, as work interference with family (WIF) and family interference with work (FIW) (Greenhaus \& Beutell 1985; Gutek, Searle, \& Klepa, 1991; Netemeyer, Boles, $\&$ McMurrian, 1996). Netemeyer et al. (1996) proposed that work family conflict consists of three different forms; as time based, strain based and behavior based. Time based conflicts occur the time spent to perform work (family) responsibilities interfere with performing the family (work) responsibilities. Strain based conflicts create stress/strain generated from work (family) interfere in performing the family (work) responsibilities. Behavior based conflicts occur when certain behaviors required in one role are incompatible with behavioral expectation in another role. 
Individuals are belong to specific roles in their work and family lives (mother/father, daughter/son, neighbor, boss, collogue, subordinate etc.) and suppose to fulfill requirements that generated from those roles. Work family conflicts create when individuals are unable fulfill those (Mete et al., 2014). Irregular work hours, overtime, less autonomy, low salary, less support from the supervisor, and negative work relations with coworkers exist at work, which are particular causes for work family conflict. At the same time family expectations, aging parents, responsibilities of children, health condition are other vital reasons that create work family conflict (Frone, Russell, \& Cooper, 1997; Nielson, Carlson, \& Lankau, 2001; Nohe, Meier, Sonntag, \& Michel, 2015; Parasuraman, \& Simmers, 2001).

Work family conflict results negative consequences on individual health (psychological strain, burnout and substance abuse) and organizational performance such as higher turnover intentions, absenteeism, lateness, dissatisfaction, distress and lower commitment towards organization and career (Eby, Casper, Lockwood, Bordeaux, \& Brinley, 2005; Brough et al., 2014). In addition, Waldron, Weiss and Hughes (1998) state that numerous crosssectional and longitudinal studies found that working women and being a mother give large number of experiences accompanied with better physical and mental well-being rather an unemployed and a married women. Moreover, fulfilling both work and family responsibilities absorb employees energy, hope, self-esteem and hinder satisfaction of work and family life equally (Aryee, Srinivas, \& Tan, 2005; Karatepe, 2011).

\section{Job Demands}

Job demands and resources (JD-R) model/theory classified the characteristics at working environment into two main cat- egories, namely; job demands and job resources (Bakker \& Demerouti, 2008; Demerouti, Bakker, Nachreiner, \& Schaufeli, 2001). Job demands are the characteristics of the job that required constant physical and mental effort by an individual. Job demands require substantial energy and skills, involve physiological and psychological costs that create exhaustion and burnout. Further, those demands can be challenging that generated through higher workload and difficult tasks that obstruct attaining the organizational goals (Li, Jiang, Yao, \& Li, 2013; Broeck, Ruysseveldt, Vanbelle, \& Witte, 2013; Tadić, Bakker, \& Oerlemans, 2015) where reduce positive well-being of the employees. The principle suggested by the job demands and resource model/theory is that combinations of job demands and resources determine employee well-being (Bakker \& Demerouti, 2007). Higher focus on completing work assignments interfere fulfilling family responsibilities, and create work family conflict ( $\mathrm{Li}$ et al., 2013; Broeck et al., 2013; Tadić et al., 2015). Greenhaus and Beutell (1985) have argued that role pressures created from work and family domains are mutually incompatible in some circumstances, which create work family conflict. Further, several work family studies have identifies that work overload, working overtime, working longer hours, and work pressure which are job demands are strong predictors for work family conflict (Bakker \& Geurts, 2004; Byron, 2005; Demerouti, Bakker, \& Bulters, 2004; Eby et al., 2005; Voydanoff, 2004). Getting support from the literature the researcher propose that,

\section{Preposition 01 - There is a positive impact of job demands on work family conflict}

Job Demand Resources (JD-R) models explains that, at the time of lack of resources such as supervisor support or job control, it is difficult for employees to manage working conditions and demands (high workload or high customer demands) 
(Demerouti et al., 2001). Likewise, JD-R model suggests that workload appears to be as a factor, which demand more effort and activation of an employee, while draining his/her energy and results exhaustion. Tayfur and Arslan (2013) argued, workload act as a prominent antecedent of emotional exhaustion where it directly and indirectly affects the employees. Moreover, research has shown that job demands (ex: work pressure, work overload, emotional demands) positively relate with exhaustion, and workplace bullying while job resources (ex: social support, performance feedback) lead to employee engagement and commitment (Bakker, 2015; Bakker \& Demerouti, 2014; Bakker, Demerouti, \& Verbeke, 2004; Thisera \& Nawaratne, 2018). Thus, the researcher propose that,

Preposition 02 - There is a positive impact of job demands on emotional exhaustion

Performing higher job demands require substantial amount of energy produce stress on employees, which drain them physically and emotionally resulting exhaustion. Poor designed jobs, higher job demands and emotional demands may exhaust employees mentally as well as physically leading to energy depletion and different health problems where employees need medication to be back to a normal state where in the long run create negative organizational outcomes (Bakker, Demerouti, \& Sanz-Vergel, 2014; Li et al., 2013). Significantly, the theory has proposed that the combinations of high demands and low resources create higher level of burnout, while combinations of high job demands and high job resources produce motivation. At the same note, previous researchers have suggested that social support, autonomy and opportunities for development act as job resources and buffer negative effects of job demands on employee wellbeing (Bakker, Demerouti, \& Euwema, 2005; Xanthopoulou et al., 2007). Full filling demands from the job involve investing number of resources and energy, however, mostly limited availability of job resources make employees strained and meaningful job demands are available from the working environment, employees are tend to perform well with pleasure that aids in reducing emotional exhaustion. Hence, the researcher propose that,

Preposition 03 - Job demands moderates the effect of job resources on work family conflict

Preposition 04 - Job resources moderates the effect of job demands on work family conflict

\section{Job Resources}

As JD-R theory classified, job resources are one of the main category of characteristics in the working environment (Bakker \& Demerouti, 2008; Demerouti et al., 2001) whereas job resources are the organizational features that support in accomplishing work goals while reducing strain from job demands, and encourage the personal growth. Further, job resources become motivational factors in a job that assist in achieving organizational goals embracing job demands in a positive manner (Demerouti et al., 2001). Furthermore, job resources enhance learning and development that predict employee motivation, employee engagement, increase wellbeing and organizational outcomes (Bakker et al., 2014; Jayarathna, 2017; Tadić et al., 2015). Bakker and Demerouti (2007) suggested that social support, supervisory coaching, performance feedback, and time control are considered as job resources and were predict dedication and organizational commitment, which, in turn relate to turnover intentions.

Job resources (ex: physical, psychological, social, or organizational aspects of the job) mostly importantly, help reducing the negative effects of job demands including 
physiological and psychological costs and enhance the personal growth, learning, and development (Bakker, 2011; Bakker $\&$ Demerouti, 2007). Further, by providing job resources in terms of work social support, autonomy, opportunity for development and feedback, employees can lessen the harmful effects of job demands (Bakker, Demerouti, \& Euwema, 2005; Xanthopoulou et al., 2007). Thus, they will be able to buffer emotional exhaustion having adequate job resources at work. Moreover, as long as organizations provide work related resources is substantial in noticing and achieving employee well-being (Wright \& Hobfoll, 2004). Thus, having necessary resources at work enable employees to reduce the spillover of stress from work to family, which reduces work family conflict. Hence, individuals are in apposition to fulfill both work and family responsibilities without dissatisfying any domain. Getting support from previous literature the researcher propose that,

Preposition 05 - There is a negative impact of job resources on work family conflict

Conservation of resource theory (SOR) and Job Demand Resources theory (JD-R) argued that resources acquire a significant position in individual's life. These resources are categorized internal and external where internal resources are possessed by self or within self (ex: self-esteem), and external resources are social support, status and employment (Hobfoll, 1989). Individuals adapt and deal with job demands and environment easily, when they are able to obtain and sustain with necessary resources. This make the employees to reduce exhaustion. Moreover, Sonnentag and Fritz (2007) found that emotional social support act as job resource and aid in recovering from exhaustion. As such, Wright and Hobfoll (2004) found that as long as organization provide work related resources is significant in perceiving employee wellbeing, which suggest that support from work environment is substantial to reduce emotional exhaustion, and fatigue of an employee. Accordingly, the researcher propose that,

Preposition 06 - There is a negative impact of job resources on emotional exhaustion

\section{Emotional Exhaustion}

Job burnout is a "psychological syndrome in response to chronic interpersonal stressors on the job" (Maslach, Schaufeli, \& Leiter 2001, p. 399). The key three dimensions of burnout are emotional exhaustion, cynicism (depersonalization) and inefficacy (reduced personal accomplishment). Emotional Exhaustion (EE) is considered as the core dimension of burnout (Shirom, 1989 cited in Rubino, Volpone \& Avery, 2013). Maslach et al (2001) suggested exhaustion is the fundamental quality of burnout and clear indicator of this complex syndrome where emotional exhaustion is conceptualized as a form strain ( $\mathrm{Ru}-$ bino et al., 2013). Emotional Exhaustion is "feelings of being emotionally overextended and exhausted by one's work" (Maslach \& Jackson, 1981, p.101). Emotional exhaustion, conceptualized as "feelings of being overextended and depleted of one's emotional and physical resources" (Maslach et al., 2001, p. 399). Likewise, Mäkikangas, Hätinen, Kinnunen and Pekkonen (2011) defined emotional exhaustion as draining of emotional energy and feeling of enduring fatigue/weakness. Additionally, emotional exhaustion is the most predominant and analytical dimension, when examining organizational phenomena. Mostly people explain experience of burnout, by referring to experience of exhaustion (Maslach et al., 2001).

Psychology discipline explains that emotions are about the attitude towards how an 
individual perceived their experiences. People expose to variety of external stimuli consciously or unconsciously, while they contact with the outside world. These attitudes includes pros or cons, dislikes or likes, attachment or loneliness, where can be divided as positive and negative emotions (Lv, Xu \& Ji, 2012). Positive emotions are exhibited through better service and performance by employees, where negative emotions through aggressive behaviors, stress, strain or exhaustion. Maintaining positive emotions lead to better mental, physical health and well-being, and at the same time negative emotions lead to stress or burnout. According to Maslach et al (2001), when an individual's main job is to deal with people's problems directly, frequently, and continuously for a longer period, they are more likely to experience emotionally exhaustion and burnout.

According to the assumptions of scarcity hypothesis, time, energy and attention is limited. When people are in a difficulty in managing the responsibilities of work and life due to scarcity of these resources, go through exhaustion, where lead to worklife imbalance. Nevertheless, high work overload makes time, energy and attention scarce where enhancing the frequency of experiencing exhaustion, because when work overload is present, it reduces the time and energy that can be devoted to family life which, increase the work family conflict and reduces the work-life balance (Tayfur \& Arslan, 2013). The researcher propose that,

Preposition 07 - There is a positive impact of emotional exhaustion on work family conflict
Individuals adapt and deal with job demands and environment easily, when they are able to obtain and sustain with necessary resources. This make the employees to reduce exhaustion. As such, Wright and Hobfoll (2004) found that as long as organization provide work related resources is momentous in perceiving employee wellbeing, which suggest that support from work environment is substantial to reduce emotional exhaustion, and fatigue of an employee. According to the assumptions of scarcity hypothesis, time, energy and attention is limited. When people are in a difficulty in managing the responsibilities of work and life due to scarcity of these resources, go through exhaustion, and lead to work family conflict. On the other way, when sufficient amount of resources are available influence of job demands on strain is reduced, consequently reduce work family conflict. Hence, the researcher propose that,

Preposition 08 - There is a mediation effect of emotional exhaustion on the relationship between job resources and work family conflict

Preposition 09 - There is a mediation effect of emotional exhaustion on the relationship between job demands and work family conflict

With the support of JD-R theory and previous literature, the framework developed and the relationships are depicted in the figure 01 . 


\section{Conceptual Framework of the Research}

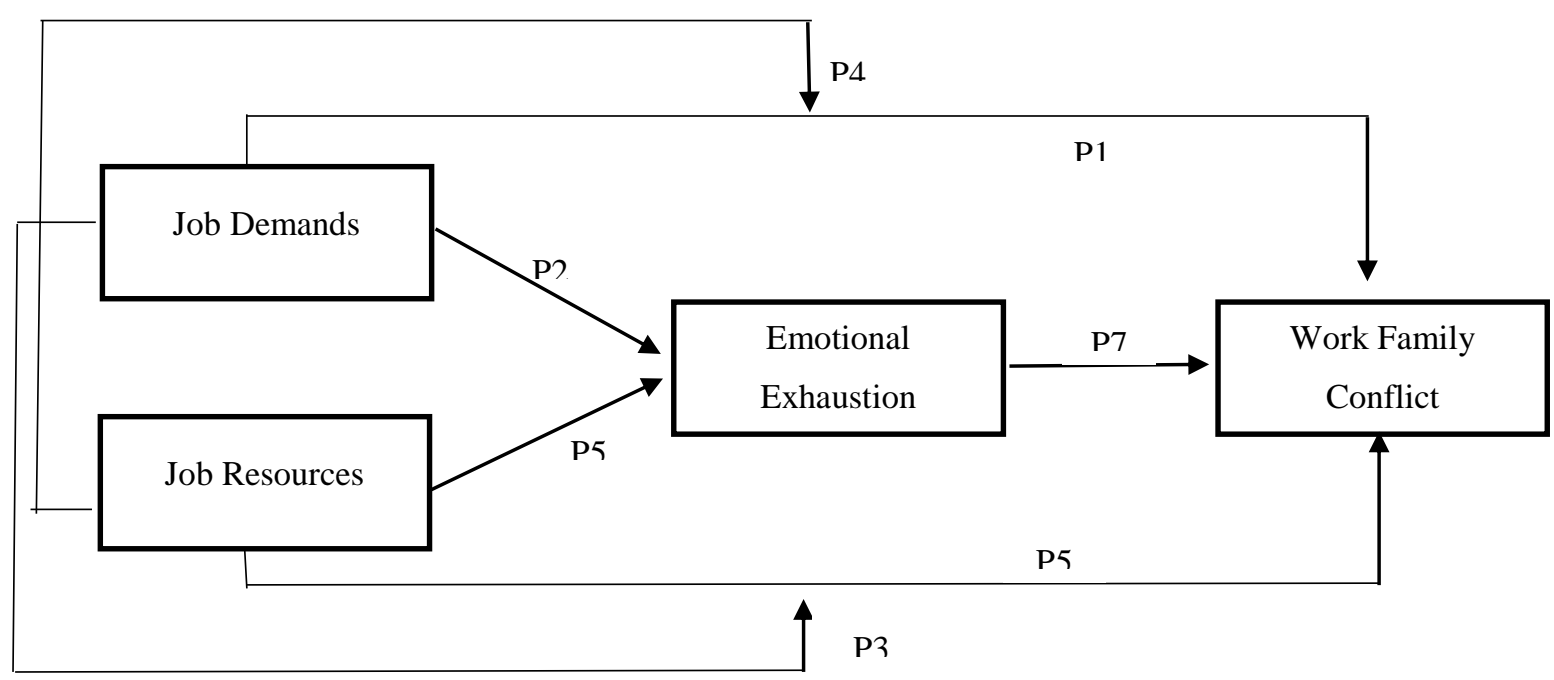

Figure 01: Conceptual Framework

\section{Conclusion and Implications of Study}

Work family conflict is a very common issue that every employee is undergoing in the current world. Hence, the attention of academics, professional and researchers have been focused on investigating the reasons and solutions for expanding boundaries of work and life domains of a human being. Therefore, the current study developed a conceptual model on work family conflict, indicating the relationships with job demands, job resources and emotional exhaustion verifying with Job Demands and Resources theory. The significance of this paper is, it propose the mediating effect of emotional exhaustion, which has not been examined to explain the relationship between job demands and job resources with work family conflict. Further, the moderating effect of job demands on the relationship between job resources and work family conflict and the moderating effect of job resources on the relationship between job demands and work family conflict were rarely examined in the previous literature. Moreover, the present study propose an Asian perspective, specially a south Asian perspective on work family conflict knowledge domain considering these mediating and moderating effects of the variables. Hence, the current study would add the knowledge in to the area of job demands, job resources, work family conflict and emotional exhaustion. Further, the study will add and extend the Job Demand and Resource model/theory to the work family domain as a novel contribution. Increasing work family conflict and emotional exhaustion, managers are looking forward with finding resolutions to make employees less exhausted and enjoy their work. Therefore, this study will make aware the managers on what factors that contribute in enhancing and reducing work family conflict and emotional exhaustion while identifying the work environment resources that create a buffer effect of negative reactions of job demands. Thus, the study make aware the managers of organizations on mechanisms, which can be used to retain the talent who are exhausted and experiencing more work family conflict. 


\section{References}

Aryee, S., Srinivas, E. S., \& Tan, H. H. (2005). Rhythms of life: antecedents and outcomes of work-family balance in employed parents. Journal of applied psychology, 90(1), 132-146.

Bakker, A. B. (2011). An evidence-based model of work engagement. Current Directions in Psychological Science, 20(4), 265-269.

Bakker, A. B. (2015). A job demands-resources approach to public service motivation. Public Administration Review, 75(5), 723-732.

Bakker, A. B., \& Demerouti, E. (2007). The job demands-resources model: State of the art. Journal of managerial psychology, 22(3), 309-328.

Bakker, A. B., \& Demerouti, E. (2008). Towards a model of work engagement. Career development international, 13(3), 209-223.

Bakker, A. B., \& Demerouti, E. (2014). Job demands-resources theory. Wellbeing. Work and Wellbeing: Wellbeing: A Complete Reference Guide, Volume III. Edited by Peter Y. Chen and Cary L. Cooper. .John Wiley \& Sons, Ltd. Published 2014 by John Wiley \& Sons, Inc. DOI: 0.1002/9781118539415.wbwell019

Bakker, A. B., \& Geurts, S. A. (2004). Toward a dual-process model of work-home interference. Work and occupations, 31(3), 345-366.

Bakker, A. B., Demerouti, E., \& Euwema, M. C. (2005). Job resources buffer the impact of job demands on burnout. Journal of occupational health psychology, 10(2), 170.
Bakker, A. B., Demerouti, E., \& SanzVergel, A. I. (2014). Burnout and work engagement: The JD-R approach. Annu. Rev. Organ. Psychol. Organ. Behav., 1(1), 389-411.

Bakker, A. B., Demerouti, E., \& Verbeke, W. (2004). Using the job demands-resources model to predict burnout and performance. Human resource management, 43(1), 83-104.

Bennett, M. M., Beehr, T. A., \& Ivanitskaya, L. V. (2017). Work-family conflict: differences across generations and life cycles. Journal of Managerial Psychology, 32(4), 314-332.

Broeck, A. V., Ruysseveldt, J. V., Vanbelle, E., \& Witte, H D. (2013). The job demands-resources model: overview and suggestions for future research. In $A d$ vances in positive organizational psychology (pp. 83-105). Emerald Group Publishing Limited.

Brough, P., Timms, C., O'Driscoll, M. P., Kalliath, T., Siu, O. L., Sit, C., \& Lo, D. (2014). Work-life balance: A longitudinal evaluation of a new measure across Australia and New Zealand workers. The International Journal of Human Resource Management, 25(19), 2724-2744.

Chandra, V. (2012). Work-life balance: Eastern and western perspectives. The International Journal of Human Resource Management, 23(5), 1040-1056.

Demerouti, E., Bakker, A. B., \& Bulters, A. J. (2004). The loss spiral of work pressure, work-home interference and exhaustion: Reciprocal relations in a three-wave study. Journal of Vocational Behavior, 64(1), 131-149.

Demerouti, E., Bakker, A. B., Nachreiner, F., \& Schaufeli, W. B. (2001). The job demands-resources model of burnout. Journal of Applied psychology, 86(3), 499512. 
Eby, L. T., Casper, W. J., Lockwood, A., Bordeaux, C., \& Brinley, A. (2005). Work and family research in IO/OB: Content analysis and review of the literature (1980-2002). Journal of vocational behavior, 66(1), 124-197.

Frone, M. R., Russell, M., \& Cooper, M. L. (1997). Relation of work-family conflict to health outcomes: A four-year longitudinal study of employed parents. Journal of Occupational and Organizational psychology, 70(4), 325-335.

Goswami, S. (2014). Work-life conflict among IT professionals. IUP Journal of Organizational Behavior, 13(4), 38.

Greenhaus, J. H., \& Beutell, N. J. (1985). Sources of conflict between work and family roles. Academy of Management Review, 10(1), 76-88.

Greenhaus, J. H., \& Powell, G. N. (2003). When work and family collide: Deciding between competing role demands. Organizational Behavior and Human Decision Processes, 90(2), 291-303.

Guest, D. E. (2002). Perspectives on the study of work-life balance. Social Science Information, 41(2), 255-279.

Gutek, B. A., Searle, S., \& Klepa, L. (1991). Rational versus gender role explanations for work-family conflict. Journal of applied psychology, 76(4), 560-568.

Hakanen, J. J., Bakker, A. B., \& Demerouti, E. (2005). How dentists cope with their job demands and stay engaged: The moderating role of job resources. $E u$ ropean journal of oral sciences, 113(6), 479-487.

Hekman, D. R., Bigley, G. A., Steensma, H. K., \& Hereford, J. F. (2009). Combined effects of organizational and professional identification on the reciprocity dynamic for professional employees. Academy of management journal, 52(3), 506-526.

Hobfoll, S. E. (1989). Conservation of resources: A new attempt at conceptualizing stress. American psychologist, 44(3), 513524.

James, A. (2014). Work-life 'balance', recession and the gendered limits to learning and innovation (or, why it pays employers to care). Gender, Work \& Organization, 21(3), 273-294.

Jayarathna, S. M. D. Y. (2017). A conceptual model of job burnout and work social support. Kelaniya Journal of Human Resource Management, 12(1), 1-16.

Jensen, M. T. (2014). Exploring business travel with work-family conflict and the emotional exhaustion component of burnout as outcome variables: The job demands-resources perspective. European Journal of Work and Organizational Psychology, 23(4), 497-510.

Karatepe, O. M. (2011). Do job resources moderate the effect of emotional dissonance on burnout? A study in the city of Ankara, Turkey. International Journal of Contemporary Hospitality Management, 23(1), 44-65.

Lambert, E. G., Kelley, T., \& Hogan, N. L. (2013). Work-family conflict and organizational citizenship behaviors. Journal of Crime and Justice, 36(3), 398-417.

Lee, T. W., \& Maurer, S. D. (1999). The effects of family structure on organizational commitment, intention to leave and voluntary turnover. Journal of Managerial Issues, 493-513.

Li, F., Jiang, L., Yao, X., \& Li, Y. (2013). Job demands, job resources and safety outcomes: The roles of emotional exhaustion and safety compliance. Accident Analysis \& Prevention, 51, 243-251. 
Liao, P. Y. (2011). Linking work-family conflict to job attitudes: the mediating role of social exchange relationships. The International Journal of Human Resource Management, 22(14), 2965-2980.

Lingard, H., \& Francis, V. (2005). Does work-family conflict mediate the relationship between job schedule demands and burnout in male construction professionals and managers?. Construction Management and Economics, 23(7), 733-745.

Lv, Q., Xu, S., \& Ji, H. (2012). Emotional labor strategies, emotional exhaustion, and turnover intention: An empirical study of Chinese hotel employees. Journal of Human Resources in Hospitality \& Tourism, 11(2), 87-105.

Mäkikangas, A., Hätinen, M., Kinnunen, U., \& Pekkonen, M. (2011). Longitudinal factorial invariance of the Maslach Burnout Inventory-General Survey among employees with job-related psychological health problems. Stress and Health, 27(4), 347-352.

Maslach, C., \& Jackson, S. E. (1981). The measurement of experienced burnout. Journal of organizational behavior, 2(2), 99-113.

Maslach, C., Schaufeli, W. B., \& Leiter, M. P. (2001). Job burnout. Annual review of psychology, 52(1), 397-422.

Mete, M., Ünal, Ö. F., \& Bilen, A. (2014). Impact of work-family conflict and burnout on performance of accounting professionals. Procedia-Social and Behavioral Sciences, 131, 264-270.

Netemeyer, R. G., Boles, J. S., \& McMurrian, R. (1996). Development and validation of work-family conflict and familywork conflict scales. Journal of applied psychology, 81(4), 400-410.
Nielson, T. R., Carlson, D. S., \& Lankau, M. J. (2001). The supportive mentor as a means of reducing work-family conflict. Journal of vocational behavior, 59(3), 364-381.

Nohe, C., Meier, L. L., Sonntag, K., \& Michel, A. (2015). The chicken or the egg? A meta-analysis of panel studies of the relationship between work-family conflict and strain. Journal of Applied Psychology, 100(2), 522-537.

Parasuraman, S., \& Simmers, C. A. (2001). Type of employment, work-family conflict and well-being: a comparative study. Journal of Organizational Behavior, 22(5), 551-568.

Patel, D. (2011). Occupational travel. Occupational medicine, 61(1), 6-18.

Rubino, C., Volpone, S. D., \& Avery, D. R. (2013). Burnout on Mars and Venus: exploring gender differences in emotional exhaustion. Gender in Management: An International Journal, 28(2), 74-93.

Sonnentag, S., \& Fritz, C. (2007). The Recovery Experience Questionnaire: development and validation of a measure for assessing recuperation and unwinding from work. Journal of occupational health psychology, 12(3), 204-221.

Tadić, M., Bakker, A. B., \& Oerlemans, W. G. (2015). Challenge versus hindrance job demands and well-being: A diary study on the moderating role of job resources. Journal of Occupational and Organizational Psychology, 88(4), 702-725.

Tayfur, O., \& Arslan, M. (2013). The role of lack of reciprocity, supervisory support, workload and work-family conflict on exhaustion: Evidence from physicians. Psychology, health \& medicine, 18(5), 564575. 
Thisera, T. J. R., \& Nawaratne, N. N. J. (2018). Asian Journal of Empirical Research. Asian Journal of Empirical Research, 8(6), 195-207.

Valk, R., \& Srinivasan, V. (2011). Workfamily balance of Indian women software professionals: A qualitative study. IIMB Management Review, 23(1), 39-50.

Voydanoff, P. (2004). Implications of work and community demands and resources for work-to-family conflict and facilitation. Journal of Occupational Health Psychology, 9(4), 275.

Waldron, I., Weiss, C. C., \& Hughes, M. E. (1998). Interacting effects of multiple roles on women's health. Journal of health and social behavior, 216-236.
Winefield, H. R., Boyd, C., \& Winefield, A. H. (2014). Work-family conflict and well-being in university employees. The Journal of psychology, 148(6), 683-697.

Wright, T. A., \& Hobfoll, S. E. (2004). Commitment, psychological well-being and job performance: An examination of conservation of resources (COR) theory and job burnout. Journal of Business \& Management, 9(4).

Xanthopoulou, D., Bakker, A. B., Dollard, M. F., Demerouti, E., Schaufeli, W. B., Taris, T. W., \& Schreurs, P. J. (2007). When do job demands particularly predict burnout? The moderating role of job resources. Journal of managerial psychology, 22(8), 766-786. 